\title{
Labor resource as a factor of modern agricultural production
}

\author{
Svetlana M. Kurbatova ${ }^{1, *}$, Larisa Yu. Aisner ${ }^{2}$, and Oleg D. Naumov ${ }^{3}$ \\ ${ }^{1}$ Assoc. Prof., Candidate of Sciences, law Institute, Krasnoyarsk State Agrarian University, Krasnoyarsk, Russia \\ ${ }^{2}$ Assoc. Prof., Candidate of Science, law Institute, Krasnoyarsk State Agrarian University, Krasnoyarsk, Russia \\ ${ }^{3}$ Senior Lecturer, Candidate of Science, law Institute, Krasnoyarsk State Agrarian University, Krasnoyarsk, Russia
}

\begin{abstract}
The article discusses the personnel problem as an important factor in the development and digitalization of Russian economy in the field of agriculture. The problems of modern labor resources in agricultural production are highlighted. The ways of addressing the problems are explored: changing social working conditions, increasing motivational components both in the state policy in the field of agriculture and in the development of methods and mechanisms for managing labor resources at specific enterprises with special reference to the particular features of their production; creating the necessary modern infrastructure, updating the content of educational programs, training, retraining and professional development, improving the management mechanisms of the industry, etc.
\end{abstract}

\section{Introduction}

One of the main challenges of our time is the exhaustion of the possibilities of economic growth in Russia. Russia's economy is based on the extensive exploitation of raw materials. On one hand, it faces development of digital economy, on the other - the emergence of a limited group of countries with new production technologies, who are focused on the use of renewable resources. The "Strategy for scientific and technological development of the Russian Federation" approved by the presidential decree No. 642 dated December 1, 2016 tackles the above-mentioned challenges [1] and reflects the content of the State program for the development of agriculture and regulation of markets for agricultural products, raw materials and food 14.07.2012 [2].

"Accelerated implementation of digital technologies in the economy and social sphere" was among the priorities of the decree of the President of the Russian Federation dated May 7, 2018 No. 204 "On the national goals and strategic development of the Russian Federation for the period until 2024" [3]. In 2019 the Passport for the national project "National program "Digital economy of the Russian Federation"[4] was prepared, aimed at implementing the following key areas of economic and social transformations:

- formation of the new regulatory environment for relations between citizens, business and the state arising out of the development of digital economy;

- creating modern high-speed data storage, processing and transmission infrastructure, ensuring stability and security of its operation;

- formation of a training system for digital economy;

- support for the development of prospective "end-toend" digital technologies and projects for their implementation;
- improving the efficiency of public administration and public services through the introduction of digital technologies and platform solutions.

At the same time, much attention is paid to the personnel issue. The Federal project "Personnel for digital economy" was developed within the framework of the program. The project aims to provide training of highly qualified personnel for the digital economy through the implementation of the following issues:

- human development;

- formation of the information space taking into account the needs of citizens and society in obtaining highquality and reliable information;

- development of various educational technologies, including distance learning and e-learning, and educational programs;

- implementation of partner programs between higher education institutions and Russian high-tech organizations; upgrading educational programs;

- development of technologies that would provide online communication between citizens, organizations, governmental and local self-government bodies, while ensuring the possibility of interaction between citizens and these organizations and bodies without information technologies;

- stimulation of Russian employees to find ways to remote employment;

- creation of management and monitoring systems based on information and communication technologies in all spheres of public life.

Since agriculture is an integral part of the economy and one of its main branches, everything mentioned above fully applies to it. However, given that, agriculture uses limited factors of production, which are divided into material resources (land and capital) and intangible resources (labor and information), the digitalization of

\footnotetext{
* Corresponding author: sveta_kurbatova@mail.ru
} 
agricultural industry requires a special approach [5]. This approach should include not only the process of collecting and accumulating information and resourcebased knowledge, best management practices, the use of new technologies, know-how, etc. The approach should involve a whole body of scientific knowledge (breeding, crop and livestock farming), technical production (including factors of production: labor, land, capital, characterized by seasonality), administrative, financial, commercial development of the means of production. The distinctive feature is the dynamic and specific conditions of agricultural production, which is a performance increase factor for "entrepreneurial ability" of the managers of agricultural organizations. Work is a purposeful activity of people that requires the involvement of mental and physical efforts to transform objects of nature into goods and services to meet their needs. [6].

Therefore, in order to implement these directions in the agricultural sector, it is necessary to understand and take into account its labor peculiarities.

\section{Features of work in rural areas}

In agriculture, labor has a number of important features:

1. The degree of labor use depends on the seasonality of production and climatic conditions. Seasonality also generates:

- instability of earnings (the staff receives more income during the summer period);

- frequent use of irregular working hours (which leads to increased fatigue of employees, reduced performance and increased stress);

- in order to perform the work in full, agricultural organizations often resort to attracting temporary staff not under an employment contract, but under a civil contract. A civil contract is not profitable for employees either in terms of their material benefits or in terms of social protection provided by labor legislation for persons working under an employment contract;

- extra free time, which contributes to the emergence of an asocial lifestyle, alcoholism.

2. Unlike other industries, the labor of an agricultural worker involves living organisms (plants, animals, and soil) in the production process;

3. Those working in rural areas have to work not only for agricultural organizations but also at their private farms, where products are also produced. As a result, people receive a double load on the body, which negatively affects their overall ability to work.

4. In rural areas, compared to the city, the social conditions for work, living and recreation are different, which determines:

- significant outflow of the population, especially among young people, to the city.

- as a result, agricultural production is characterized by

"aging" due to the unattractiveness of agricultural labor for young people;

- as a result, this affects labor productivity, since for most elderly people, despite their qualifications and professional skills, physical labor becomes a burden, which reduces its productivity

5. In comparison with other sectors of the national economy, more pensioners, teenagers and women are involved, a significant part of the work is lowmechanized and involves the use of unskilled manual labor.

6. Low level of education. Because the vast majority of employees are representatives of the "production personnel" category, the general level of education in agricultural enterprises is often average or lower (most employees have primary or secondary vocational education - vocational schools, lyceums, technical schools, colleges), which:

- limits career opportunities (and this is despite the fact that due to the specifics of agricultural production, they are already limited);

- contributes to staff turnover (employees do not value the workplace as such, work for the sake of wages and leave for other organizations when there is an opportunity;

7. Both above-mentioned factors affect the ability and effectiveness of professional development and retraining which is especially important in the view of digitalization of the agricultural industry.

8. There are serious problems with the reproduction of the human factor: a decrease in life expectancy, high mortality (due to diseases, injuries, asocial factors, etc.), an increase in natural and forced unemployment, a shortage of skilled workers, high-quality managers, and differentiation in the quality of life.

It should be borne in mind that at the end of the previous century in Russia there was a serious quantitative and qualitative loss of the personnel in the agricultural sector because of the perestroika reforms of the $80 \mathrm{~s}$ and economic decline of the $90 \mathrm{~s}$; the economic crisis of 2008-2011 worsened the situation. Those factors have formed a multi-year "gap" in the way of development of the Russian economy in general and agriculture in particular.

As a result, in order to transfer the agricultural economy to higher, digital, level other measures should be taken than what is currently being done.

\section{Formation of growth of quantitative and qualitative characteristics of labor in agricultural production as a task for Russia}

The features of labor in agricultural production are the cause of the low quality and quantitative indicators of labor efficiency in the agricultural sector. They negatively affect the efficiency of agricultural production in general and threaten the implementation of tasks and measures to digitalize the agricultural sector of the Russian economy.

This determines the need for a clear system of these indicators. A system that reflects understanding of:

- features and problems of the agricultural sector of economy in general;

- specifics of labor as a factor affecting its effectiveness; 
- the need to develop an optimal socio-economic, institutional mechanism for the reproduction and use of human resources, which should include such components as: civilizational, historical, economic globalization, the state of scientific and technological progress, the state of the market, human education, and morality.

- the importance of motivational processes, and, as a consequence, the need to interest young professionals, high-quality professionals, foreign specialists and attract them to the agricultural industry [7];

- the importance of investing in each specialist and preserving them, as an investment including. It is vitally important since the knowledge that they received both in the course of training and in the future give the output of a high-quality labor unit in agricultural production [8].

- the need not only to promote, but also to introduce a healthy lifestyle, culture of behavior, moral, ethical and spiritual education, and legal awareness into society;

- understanding the role of medical and social services for the population;

- the importance of fixing relevant concepts in educational and scientific systems, taking into account the innovative and digital indicators of the effectiveness of getting knowledge;

- developing the system of career guiding that would promote young people to choose career in agriculture; - the need to change the existing societal mentality that rural lifestyle and work in rural areas are not prestigious; - the need to consolidate the state and business in solving socio-economic issues, etc.

Such a system supported by legal mechanisms will indicate:

- real awareness of the importance and significance of the agricultural sector of the economy for the state;

- real application of an integrated approach for state policy in the field of agriculture, including training specialists for the sustainable development of rural territories [9];

- understanding applicable financial mechanisms and others.

The role of motivation for developing measures to preserve and attract high-quality labor in agriculture require special attention [10]. The moral and material interests of employees in achieving high labor results is something that should be studied and applied when creating a model of attractiveness of agricultural labor and it should be the basis of the state policy in solving the personnel issue for the agricultural economy.

In addition, a well-formed state policy in the field of education is of great importance, given that knowledge acts as the main source of labor productivity growth, makes it possible to introduce innovations in the production process, and also determines the competitive advantages of the enterprise in the market [11], solving the issue of personnel support for rural economy branches [12] and influencing the processes of personality formation [13].

Future policy should include tapping of foreign expertise on certain specific areas [14, 15]

Market leadership will belong to innovative companies, giving special importance to the development and effective use of human capital of their employees. The problem of ensuring efficient use of human capital as the main instrument to increase the competitiveness of agricultural enterprises of the majority of enterprises of agro-industrial complex is not just only relevant. It is among a number of priority tasks in the system of social and economic research [16], therefore, agriculture should become an object of close attention from the highest authorities of the Russian Federation.

\section{Conclusions}

The main reasons why labor is currently a weak link in the agricultural sector of the Russian economy are:

- the absence of real reflection of the modern theory of the human factor in the market economy and comprehensive approach to its reproduction and use;

- ignoring the relationship between its socio-economic and institutional forms;

- preservation of the historical tendency to consider the reproduction of this factor on a residual basis; - absence of an effective mechanism for its functioning in Russian agricultural economy, which should be based on the law of advanced formation of human resources investments;

- lack of appropriate methods for forecasting and regulating its quantitative and qualitative indicators. As a result, many negative phenomena such as decrease in the level of education and increase in in the level of unemployment become stable trends in the reproduction of human resources in rural areas and are often perceived as objective and inevitable phenomena of economy.

It is also necessary to understand that:

- employees have different levels of accumulated human capital, i.e. they have different levels of health, general and professional knowledge, moral qualities, labor skills, innate abilities, social image and connections [17].

- in the end, the quality of the company's human capital will depend on measures that would allow to accumulate and improve the individual human capital of each employee [18].

It is important to take into account the motivational aspirations of current and potential employees, using motivation as a factor that stimulates the development of human resources in agriculture.

A special attention should be paid to the education system as a mechanism for the transfer and formation of knowledge and the process of educating a person as a legal, self-sufficient person.

This should be taken into account when implementing long-term planning and regular updating of priority scientific and technical projects that would allow:

- form competitive teams (that unite researchers, developers and entrepreneurs);

- develop targeted support measures for young scientists and specialists in the field of scientific, technical and innovative activities;

- create a competitive environment open to high-quality specialists; 
- attract private investment and funds from the Federal, regional and local budgets;

- innovative projects to create social infrastructure necessary to ensure a decent standard of living for people engaged in agricultural production.

\section{References}

[1] Decree of the President of the Russian Federation dated 01.12.2016, no. 642, "Strategy of scientific and technological development of the Russian Federation" (2016) [Electronic resource]. Available at: http://www.consultant.ru/cons/cgi/ online.cgi?req $=$ doc\&base $=$ LAW\&n $=207967 \&$ fld $=$ $134 \& \mathrm{dst}=100015,0 \& \mathrm{rnd}=0.16695426166329508 \#$ 06926486497907463.

[2] Decree of the government of the Russian Federation dated 14.07.2012, no. 717, ed. from 18.12.2019, "On the State program of development of agriculture and regulation of markets of agricultural products, raw materials and food" [Electronic resource]. Available at: https://base.garant.ru/70210644/.

[3] Decree of the President of the Russian Federation dated 07.05.2018, no. 204, "On the national goals and strategic objectives development of the Russian Federation for the period up to 2024" [Electronic resource]. Available at: http://www.consultant.ru/cons/cgi/online.cgi?rnd= 2D7501BA6AD41743377E30BF5352DE2B\&req= doc \&base $=$ LAW $\& n=303020 \&$ REFFIELD $=134 \&$ REFDST $=101623 \&$ REFDOC $=328933 \&$ REFBAS $\mathrm{E}=\mathrm{LAW} \& \mathrm{sta}=$ refcode\%3D10881\%3Bindex\%3D1 785\#16wh4b2ozbl.

[4] Passport of the national project "national program", Digital economy of the Russian Federation, UTV. by the Presidium of the presidential Council for strategic development and national projects, protocol no. 7 of 04.06.2019.

[5] S.M. Kurbatova, L.Yu. Aisner, V.V. Naumkina, Some aspects of the essence and legal regulation of agriculture digitalization as one of the priorities of modern state policy of agriculture development. Agritech, IOP Conf. Series: Earth and Environmental Science, 315, 032021 (2019). DOI: 10.1088/1755-1315/315/3/032021.

[6] A.A. Shamin, A.E. Shamin, The Role of the main factors in agricultural organizations [Electronic resource]. Available at: http://cyberleninka.ru/ article/n/rol-osnovnyh-faktorov-v-selskohozyayst vennyh-organizatsiyah.

[7] S.V. Semykina, The Human factor and its socioeconomic and institutional forms in the modern economy, Bulletin of the Kursk state agricultural Academy, 6, 7-11 (2010).

[8] N.V. Sharapova, Human capital. Its influence on the competitiveness of agriculture, Agrarian Bulletin of the Urals, 10, 177, 87-94 (2018).

[9] E.V. Dadayan, A.N. Storozheva, V.V. Zhalybin, On the issue of training a graduate lawyer for the sustainable development of rural territories and agriculture, Legal policy and legal life, 4, 91-95 (2017).

[10] Sh.D. Arslanov, A.G. Gadzhieva, Development of agriculture: motivation of labor, Regional problems of economic transformation, 10, 31-37 (2016).

[11] A.G. Rusakov, Corporate forms of organization and support of entrepreneurship in the agricultural sector of the region, Economy and management in modern conditions, All-Russian scientific and practical conference, Krasnoyarsk, 133-142 (2006).

[12] S.M. Trashkova, L.Yu. Aisner, Some regulatory and legal aspects of the development of personnel support for rural economy branches as part of state policy at the present stage, Agrarian and land law, 4, 148, 26-28 (2017).

[13] L.Yu. Aisner, S.M. Trashkova, The Role of education in the formation of personality, Kazan science, 10, 126-128 (2017).

[14] L.Yu. Aisner, S.V. Bershadskaya, Higher education as a factor of life success of rural youth in Great Britain, Collection of materials of the International scientific and practical conference: Problems of formation of value orientations in education of rural youth, 143-144 (2014).

[15] S.V. Bershadskaya, Agrarian education in the USA, Proceedings of the international scientific conference: Problems of modern agricultural science, 392-395 (2019).

[16] E.M. Semenova, A. Arsenin, Features of human capital development of agricultural enterprises personnel, Economics: yesterday, today, tomorrow, 6, 12B, 362-374 (2016).

[17] R. Kramar, Beyond strategic human resource management: is sustainable human resource management the next approach?, The international journal of human resource management, 25, 8, 1069-1089 (2014).

[18] A.A. Katou, P.S. Budhwar, Human resource management systems and organizational performance: a test of a mediating model in the Greek manufacturing context, The international journal of human resource management, 17, 7, 1223-1253 (2006). DOI: 10.1080/0958519060075 6525 . 